\title{
A MÉLTÁNYOS KERESKEDELEM MOZGALMÁNAK ÁTTEKINTÓ BEMUTATÁSA
}

\author{
- no — \\ OVERALL INTRODUCTION OF THE FAIR TRADE INITIATIVE
}

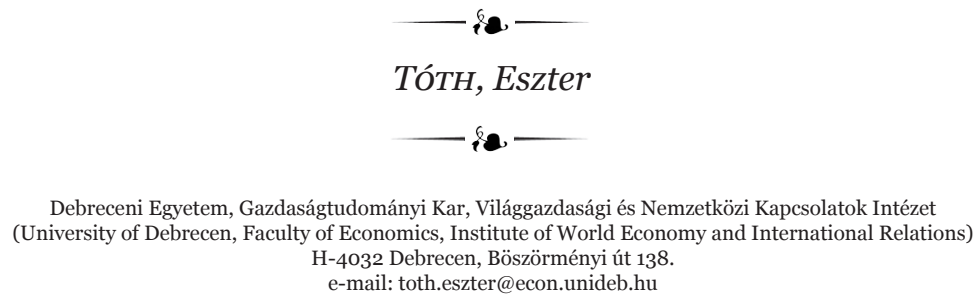

\begin{abstract}
gi Fair trade is a bottom-up initiative whose objective is to make reasonable conditions for the poor producers of the Third World and to enable them to follow a sustainable model of development. This realigned commercial partnership aims to modify the rules of traditional international trade between the producers of the southern nations and the purchasers of the northern hemisphere, and to replace them with a novel alternative. The goal of fair trade is to change the rules of the game that have controlled the dominant economic model. The main tool of the movement is the development of an awareness of socially responsible consumer behavior.
\end{abstract}

KulCsSZAVAK: gazdasági etika, fenntartható fejlődés, méltányos kereskedelem, tudatos vásárlás

\section{BEVEZETÉS - INTRODUCTION}

Felgyorsult világunkban egyre nagyobb hangsúlyt kapnak a különböző „slow” mozgalmak és a tudatos vásárlást, tudatos fogyasztást középpontba állító kezdeményezések. Az etikai elveket figyelembe vevő méltányos kereskedelemnek a célja, hogy a világ déli szegény termelői számára segítséget (de ne segélyt!) nyújtson és egy rendhagyó gazdasági modellt kínáljon számukra. A méltányos kereskedelem, azaz a „fair trade” célja az eddigi domináns kereskedelmi rendszer megváltoztatása, ehhez pedig legfőbb eszköze a tudatos és felelősségvállalásra kész fogyasztói magatartás kialakítása.

Cikkemben ezt a mozgalmat helyezem középpontba, és egy rövid irodalmi áttekintés során bemutatom a kezdeményezés legfőbb ismertető jegyeit, előnyeit, kritikáit.
KEYWORDS: business ethics, sustainable development, fair trade, conscious consumption

\section{A MÉLTÁNYOS KERESKEDELEM MOZGALMÁNAK ELMÉLETI ISMER- TETÉSE - THEORATICAL INTRODUCTION OF THE FAIR TRADE INITIATIVE}

A méltányos kereskedelem [1; 2] „egy párbeszéden, átláthatóságon és tiszteleten alapuló kereskedelmi partnerség, amely növekvő egyenlőségre törekszik a nemzetközi kereskedelemben" [3, 3. o.]. Az alulról jövő civil kezdeményezés célja a hagyományostól eltérő játékszabályok alkalmazásával egy alternatív kereskedelmi rendszer bevezetése, amely magas minőségű (általában mezőgazdasági) termékek előállításán és értékesítésén keresztül támogatja a mozgalomhoz csatlakozott termelőket a Harmadik Világ országaiban. A szervezetben való részvétel regisztrációhoz - licensz vásárlásához - kötött, ami bizonyos gazdasági, környezeti, szociális szabályok 
és munkafeltételek [4] betartását követeli meg a termelőktől. Ezért cserébe a marginalizálódott termelők számos előnyt élveznek: jogosulttá válnak a „Fairtrade Mark” védjegy használatára, amely növelheti bevételeiket és segít megszólítani a tudatos vásárlói réteget; tisztességes árat kapnak a termékeikért; kérhetik a szerződésük részbeni előfinanszírozását; kereskedelmi partnereikkel hosszú távú kapcsolatokat és megbízható piacrajutási lehetőséget építhetnek ki; valamint a termékek eladása után járó úgynevezett „prémium” összegből helyi fejlesztési vagy oktatási projekteket finanszírozhatnak. Értékesítési láncként a mozgalom gyakorlati eszköze a lánc kiiktatható elemeinek elhagyása, a kereskedők számának csökkenésével pedig az értéklánc rövidülése, aminek következtében a termelők az értékesítési ár magasabb hányadával gazdálkodhatnak.

A fair trade tehát egy „,szokatlan üzleti kapcsolat a termelővel, mint elsődleges érintettel” [5, 77. o.]. A mozgalom missziója a hátrányos helyzetben lévő termelők életszínvonalának növelése a fenntartható fejlődésen, a szociális, gazdasági és környezeti célok elérésén keresztül. Ennek érdekében a fair trade világszervezete (World Fair Trade Organisation - WFTO) [6] 2013 októberében a következő célokat fogalmazta meg:

- Lehetőségek teremtése a gazdaságilag hátrányos helyzetben lévő termelő számára

- Átláthatóság és elszámoltathatóság garantálása

- Méltányos kereskedelmi gyakorlatok alkalmazása

- Méltányos ár fizetése

- A gyermekmunka és a kényszerített munka tilalma

- A diszkriminációmentesség, a nemek közötti egyenlőség, a nők gazdasági szerepvállalása és az egyesülés szabadsága melletti elköteleződés

- Jó munkafeltételek biztosítása

- A szervezetfejlesztés lehetőségének megteremtése

- A fair trade mozgalom terjesztése

- A környezet tiszteletben tartása [7]

A fair trade termékeket előállító szervezetek formája alapvetően kétféle lehet: a gazdálkodók kis termelői szervezetekbe tömörülhetnek (small producer organisation), amelyben jellemzően saját maguk és családtagjaik tevékenykednek, vagy bérmunkások segítségét vehetik igénybe a termeléshez (hired labour organisation). A fair trade központi szervezete, a Fairtrade International (FLO) [8], mindkét szervezeti formára vonatkozóan, sőt, a méltányos termékeket forgalmazó kereskedelmi szereplők számára is külön standardokat határoz meg, amelyek betartása garantálja a fenti célok elérését. A standardok részletesen definiálják a mozgalomhoz csatlakozni kívánók számára a kötelező vállalásokat. Rendezik a termék minősítésével kapcsolatos tudnivalókat, a fair trade termékek nyomonkövetésének technikai és adminisztrációs lépéseit, előírják a termelő vállalkozás szervezeti felépítését, a környezetvédelem érdekében elvárt tevékenységeket és a tiltott vegyszereket, a munkaszervezés kapcsán kiemelkedő jelentőséggel bíró szempontokat (különös tekintettel a gyermekek és nők munkában való részvételére). Az általános standardokat az adott termékre vonatkozó specifikus szabványok egészítik ki, amelyek tovább részletezik és szigorítják a védjegy megszerzésének feltételeit.

\subsection{A fair trade termékek köre - Fair Trade Product Range}

A méltányos kereskedelem mozgalma ma már a világ 74 országában van jelen, több mint másfél millió embernek adva munkát ezzel. A méltányos kereskedelmet koordináló FLO legfrissebb évkönyve alapján a 2012-2013-as időszakban 944 millió euró összegben értékesítettek fair trade termékeket a világban [9].

A méltányos kereskedelem által kínált termékek köre kezdetekben kifejezetten a különböző kézműves technikákkal készült árukra korlátozódott. A fair trade termékek vertikuma idővel a mozgalom és a kereslet növekedésével együtt bővült. Az első „méltányosan kereskedett” élelmiszer a kávé volt 1973-ban, ez napjainkra az egyik legkedveltebb fair trade termékké vált. A kávét sorban követte a többi mezőgazdasági árucikk, és mára a banán, cukor, tea, bor, friss és aszalt gyümölcsök, méz mellett vágott virág és pamut is származik méltányos ültetvényekről. A mezőgazdasági árufajtákon kívül a hivatalos fair trade termékek között [10] megtalálhatjuk még a faanyag, arany és egyéb nemesfémek, sportlabdák kategóriáit is, de a kézmúves, textil és ruházati termékek, valamint újabban a turizmus [11] mint szolgáltatás minősítése is egyre gyakoribb.

A 70 éves múltra visszatekintő mozgalom elsősorban tehát a mezőgazdasági termékek kereskedelmében érintett, hiszen ezek termelése jellemző a világ szegény déli országaiban. A tíz legnagyobb értékben eladott fair trade terméket listázza az 1. táblázat. Az értékesítés erősen koncentrált: az első öt termék dominálja a piacot és képviseli az összes eladás 91,2\%-át. 
1. TÁBLÁZAT

TABLE 1

A fair trade termékek értékesítéséből származó termelői bevételek (2012-2013, millió euró) (Producer Sales Income Reported from Fairtrade Sales (2012-13, € millions))

\begin{tabular}{clc}
\hline & \multicolumn{1}{c}{$\begin{array}{c}\text { Termék neve } \\
\text { (Product Name) }\end{array}$} & $\begin{array}{c}\text { Bevétel, milló euró } \\
\text { (Sales Income, euro millions) }\end{array}$ \\
\hline 1 & Kávé (coffee) & 518,5 \\
\hline 2 & Banán (bananas) & 137,1 \\
\hline 3 & Kakaó (cocoa) & 96,1 \\
\hline 4 & Cukornád (cane sugar) & 61,8 \\
\hline 5 & Virág, növény (flowers, plants) & 47,3 \\
\hline 6 & Tea (tea) & 16,3 \\
\hline 7 & Friss gyümölcs (fresh fruits) & 13,8 \\
\hline 8 & Borszőlö (wine grapes) & 9,7 \\
\hline 9 & Gyógynövény, herbatea, füszerek (herbs, herbal teas, & 7,4 \\
\hline 10 & Qpices) & 6,8 \\
\hline
\end{tabular}

Forrás (Source): [9] alapján saját szerkesztés (own compilation based on [9])

A fair trade termékek kinézetükben nem, vagy csak alig különböznek a hagyományos előállítású társaiktól. Különlegességük abban rejlik, hogy a tudatos vásárlók meggyőződése alapján ezek a termékek magasabb minőségi, komolyabb környezeti, társadalmi szempontok betartása mellett születtek. Míg általánosságban a fogyasztót csak a vásárolt termék funkcionalitása, a használat közbeni megfelelősége érdekli, addig Steinrücken és Jaenichen [12] szerint egy áru hasznosságát két részre oszthatjuk, és a funkcionalitáson kívül meghatározó tényező a termék kiegészítő hasznossága. Kiegészítő hasznosságról akkor beszélhetünk, ha a praktikumot túlhaladva, valamely más, például etikus, környezetvédő vagy egészségtudatos életstílust, társadalmi felelősségvállalást is támogat, szolgál az áru. A fair trade termékek esetében a kiegészítő hasznosság kulcsa a termelő jóléte és anyagi boldogulása. Egy fair trade banán ugyanazt „tudja”, mint hagyományos párja, mégis olyan etikai hozzáadott értékkel bír, amely sokat jelent az elkötelezett vásárlóknak. Az elmúlt évek piaci trendjei igazolják a tudatos vásárlói körök megerősödését, amire példaként szolgál a LOHAS fogyasztók számának emelkedése, akik egészség- és környezettudatos elvek mentén haladva hozzák meg fogyasztói döntéseiket [13]. Fogyasztók egy másik csoportjának a termelés módja jelent megkülönböztető értéket és ezen külső minőség [14; 15] alapján határoznak a méltányosan termelt áruk megvásárlása mellett.

\subsection{A méltányos termékek árazása - \\ Pricing Policy of Fair Trade Products}

A közgazdaságtan alapvetése, hogy a piacot az ár szabályozza és a fogyasztó, aki homo oeconomicus-ként dönt két termék között, automatikusan az olcsóbbat fogja választani. A 21. századi valóság azonban nehezen modellezhető ilyen egyszerüen, és a fair trade termékek piacán sem így történik a döntéshozatal. A méltányos kereskedés céljainak való megfelelés, a mozgalomhoz való csatlakozás szabályainak betartása ugyanis jelentős addicionális költséggel terheli a termelőt, akinek a terméke drágább lesz, mint a konvencionális versenytársai. Az etikai megfontolások alapján döntő vásárló azonban tisztában van ezzel és a méltányosan előállított áru - magasabb ára ellenére is - nagyobb hasznosságot képvisel számára, mint hagyományos megfelelője. Választási helyzetben ennek okán a tudatos fogyasztó a drágább, de erkölcsi hozzáadott értékkel bíró változatot fogja megvásárolni. Ezt támasztja alá az a tanulmány [16], amely szerint a fair trade termékeket leginkább a 35 év körüli, jól szituált, női vásárlók keresik, akik esetenként hajlandóak a 10-20\%-os piaci „felár” megfizetésére is [5]. Egy másik, a Genti Egyetem felmérése szerint a belga „fair trade szerető” vásárló relatíve magas képzettséggel bír, 31-44 évei között jár, és akár 27\%-os extra árat is megad a választott termékért [15]. 
A méltányos kereskedelem rendhagyósága többek között az árképzésében érhető tetten. A mozgalomhoz csatlakozott termelő és kereskedője közt egy jövőre szóló szerződés köttetik, amelynek az egységárat a szerződéskötés pillanatában rögzítik. Abban az esetben, ha a teljesítéskor az aktuális piaci ár ennél magasabb lesz, akkor a kifizetést a magasabb piaci áron kell lebonyolítani; azonban, ha a piac ár a pénzügyi rendezés napján alacsonyabb, mint az előre rögzített érték, akkor ezt a korábban kialkudott árat kell alkalmazni. Ez a minimális, fix ár a méltányos ár, ami egyfajta biztonsági garanciaként múködik a tranzakciók folyamán. Jelentősége azon túl, hogy megvédi a termelőt az árutőzsdék árainak nagy bizonytalanságot jelentő változékonyságától abban van, hogy, úgy kerül meghatározásra, hogy mindenképpen fedezze a termék elöállítási költségeit. Így a termelő védettséget élvez a globális piacok kiszámíthatatlanságával szemben és számíthat arra, hogy bevételei biztosan fedezik legalább a felmerült költségeit.

A fair árképzés az elsőszámú indok, ami miatt a termelők csatlakozni szándékoznak a mozgalomhoz. Kritikusok véleménye szerint azonban ez a lehetőség téves előnnyel kecsegtet, mivel a rögzített árak mellett nem teljesülnek azok a finomhangolások, amelyek a piac keresleti és kínálati oldalát öszszerendezik. Ez hosszú távon csak árt a gazdaságnak, hiszen az nem a kívánt egyensúlyi pontjában fog rögzülni [17].

$\mathrm{Az}$ árképzés másik érdekessége az úgynevezett fair trade prémium, amelyet minden értékesített termék egysége után kap a termelő szervezete. Ez tehát az áron felüli extra „felár”, amelyet az áru fajtájától, típusától, származási helyétől függően előre definiálnak [18]. Az értékesítés során befolyt prémium összeget szervezeti szinten gyüjtik össze, majd a tagok közösen, konszenzussal döntenek a felhasználás módjáról. Az összeget fordíthatják a termelői szervezet üzleti infrastruktúrájának fejlesztésére, képzésekre, vagy a település humán, szociális adottságainak, oktatási, gazdasági lehetőségeinek javítására. Míg az FLO 2009-es tájékoztatása szerint a prémiumokból származó bevétel 52 millió euró volt, addig a 2012-2013-as időszakban már 95 millió euró állt rendelkezésére a termelői szervezeteknek, hogy különféle projekteket támogassanak. Ebben a periódusban a kis termelői szervezetek az összegyúlt prémium felét a szervezetbe forgatták vissza helyiség- és infrastruktúrafejlesztés, képzés és kapacitásépítés, valamint a humán erőforrások és adminisztráció finanszírozása révén, a bérmunka szervezetek pedig oktatásra, pénzügyi és hitelszolgáltatásokra, egészségügyre, a lakhatási feltételeik javítására és egyéb, a munká- sok által igénybe vehető szolgáltatásokra költötték a prémiumot [9].

Az árak meghatározásán kívül vonzó lehetőség, hogy a termelők a szerződésük előfinanszírozását kérhetik a kereskedőiktől és a szerződött összeg 40-60\%-ával gazdálkodhatnak, még mielőtt a fizikai teljesítés megtörténne. A mezőgazdasági termelésben is gyakorta alkalmazott módszer nagyon fontos a forráshiányos termelők likviditási problémáinak áthidalására, hiszen a kiegyensúlyozott gazdálkodás és az anyagi függetlenség lehetőségét testesíti meg számukra. „A fair trade biztonságot, tőkét és tudást nyújt a termelőknek, hogy megfelelően diverzifikálják a bevételi forrásukat, ezáltal csökkentsék a terményeiktől való veszélyes függőséget" [19, 27. o.]. Az árutól való függőség leküzdése - mint üzleti cél - és a biodiverzitás megőrzése - mint környezetvédelmi fókusz - alapvető célja a méltányos kereskedelemnek.

\subsection{A méltányos termékek értékesítési csatornái - Distribution Channels of Fairly Traded Products}

A fair trade termékek alapvetően három csatornán keresztül juthatnak el a fogyasztókhoz, amelyek a következők:

- postai csomagküldés,

- $\quad$ specializálódott kiskereskedelmi üzletek (Világ boltok, Fair Trade boltok), vagy

- nagy kiskereskedelmi élelmiszerláncok.

Az 1940-50-es években egymástól függetlenül több olyan civil kezdeményezés alakult, amelyek célja a társadalom legszegényebb rétegeinek segítése volt újszerü kereskedelmi megoldások révén. Az egyik első ilyen alternatív kereskedelmi szervezet (Alternative Trade Organisation - ATO) az 1946-ben az Egyesült Államokban alapított Ten Thousand Village vallási szervezet volt, amely puerto ricoi kézimunkákat árult tagjai között. Európában, Angliában az 1950-es évek végén nyitott meg az első Oxfam bolt, amely a bevándorló, menekült kínaiak által készített kézmüves termékekkel foglalkozott. Kicsit késóbb, 1967-ben Hollandiában megalakult az első, már kifejezetten a méltányos körülmények között előállított termékek értékesítésére szakosodott Fair Trade Organisatie importvállalat. A vállalat 1969-ben megnyitotta Harmadik Világ boltját, amely a déli félteke országaiból hozta be termékeit, hogy ezeket értékesítve segítsék a térség termelőit. Az 1960-as, 70-es években további számos nem-kormányzati és civil szervezet alakult, abból a célból, hogy az elmaradott afrikai, ázsiai és latin-amerikai országok lakóit, termelőit támogas- 
sák kereskedelmi tevékenységeikben.

A szakosodott kiskereskedelmi boltok (Harmadik Világ boltok, Fair Trade és bioboltok) esetében a termékek megfelelő forrásból való származásának igazolására nem más szolgált, mint az értékesítési csatorna maga. Az árusítás történhetett személyesen a boltokban, vagy hagyományos és vallási ünnepekhez kötődő vásárok alkalmával [19]. Amennyiben ezeket az árukat valamelyik ATO, vagy kifejezetten fair trade kereskedő vállalat importálta, akkor ezeket a szakosodott boltokon keresztül értékesítették tovább a fogyasztóknak. A méltányos kereskedelemből származó termékek egyre jobb fogadtatásnak örvendtek a vásárlók körében, akik rutinjába beépült, hogy rendszeresen meglátogassák az áruk forgalmazását végző szakosodott boltokat.

Nagy újdonságot jelentett, amikor a holland, egyházi alapítású civil szervezet, a Solidaridad 1988-ban bevezette az első fair trade címkét (Max Havelaar ${ }^{1}$ ) mintegy megoldásként az óket megkereső mexikói kávétermelők problémájára, hogy a jó minőségü termékeiket megkülönböztethessék a többi árutól és, hogy az európai fogyasztóik könnyen kedvenc kávéjukra találhassanak a boltokban.

Míg korábban a világboltokban elérhető termékeket (speciális címke hiányában) gyakorlatilag az minősítette, hogy az adott szaküzletben értékesítették őket, az új védjegy alkalmassá tette a fair trade árukat arra, hogy a nagy kiskereskedelmi egységekben is felismerhetőek és megkülönböztethetőek legyeken a többi konvencionális terméktől. A hiper- és szupermarketeket múködtető kiskereskedelmi láncokkal és transznacionális vállalatokkal való kooperáció azonban sok támogatónak és aktivistának ellenére volt és komoly erkölcsi kihívást jelentett. Bár nyilvánvaló volt, hogy velük együttmúködve a méltányos kereskedelem eszméi nagyobb publikumhoz jutnak el - amely a mozgalom egyik fó célja -, ez azonban csak a fair trade elvek felhígulása árán volt lehetséges [20]. Kezdetben egyértelműen a szakosodott kiskereskedelmi üzletek játszották a főszerepet mind az értékesítésben, mind pedig a mozgalom ismertségét növelő rendezvényszervezés, tájékoztatás és lobbytevékenység kapcsán. A kiskereskedelmi csatornák kiterjedt disztribúciójának elfogadása óta azonban a szupermarketek is fontos szereplői a méltányos kereskedelemnek, hiszen általuk nagy tömegek érhetők el és válhatnak potenciális vásárlókká [21]. Manapság a kereskedelmi volumen meghatározó százaléka ezen vállalatok kasszáinál bonyolódik le.

A kiskereskedelmi láncok bevonása fókuszvál- tást is eredményezett a mozgalom életében: ahelyett, hogy azt várták, hogy a vásárló látogatást tegyen egy specializálódott szakboltban - gyakorlatilag - egy vagy két termékért, felajánlották neki a sokkal kényelmesebb lehetőséget, azaz, hogy mindennapos bevásárlása közben hozhatja meg a meggyőződésének, elhivatottságának megfelelő vásárlási döntést.

\subsection{A fair trade termékek kommunikációs eszközei - Promotion of Fair Trade Initiative}

Ahogy nőtt a mozgalom szimpatizánsainak száma, úgy változott a mozgalom kommunikációs stratégiája is. Egyre nagyobb hangsúlyt kezdtek fektetni a marketing és promóciós tevékenységekre, melyek tovább növelték a fair trade iránt érdeklődők számát és maga a szervezet is egyre professzionálisabb módon múködött.

A szakboltokban dolgozó alkalmazottak és önkéntesek egyik legfontosabb feladata a termékekkel kapcsolatos információk továbbadása volt: sokszor személyes történeteken keresztül és fényképeket bemutatva próbálták a déli termelőket közelebb hozni, megismertetni az északi vásárlókkal. A kommunikációnak és tájékoztatásnak ez a fajtája felülmúlta az egyszerű fogyasztói felvilágosítást. Célja a fogyasztók megnyerése és hosszú távú elkötelezése volt, azaz, hogy elérjék a vásárlóknak a méltányos kereskedelem elveivel való azonosulását és a különböző kampányokban való aktív közreműködését [12].

Az első fair trade címke alkalmazása alapjaiban változtatta meg a méltányos kereskedelem ismertségét. A Max-Havelaar [22] márkanév használatára olyan szervezetek tarthattak igényt, akik igazolni tudták, hogy áruikat méltányos körülmények között állították elő, fair módon kereskedtek velük és értékesítették azokat. A címkével ellátott kávékat holland szupermarketekben kezdték értékesíteni. A Max-Havelaar védjeggyel együtt létrejött a fair trade termékek intézményesített kategóriája, lehetőséget teremtve ezzel a direkt pozícionálásra és a többi terméktől való megkülönböztetésre.

A védjegy sikerén felbuzdulva egymás után jelentek meg a különböző címkék Európa és Észak-Amerika számos államában, használatuk egyre jobban elterjedt és a kereskedelmi szereplők is meglátták az ebben rejlő lehetőségeket. A Max-Havelaar címke Belgiumban, Svájcban, Dániában, Norvégiában és Franciaországban volt jelen, a Transfair az Amerikai Egyesült Államokban, Kanadában, Japánban, Németországban,

${ }^{1}$ A védjegy egy fiktív holland irodalmi karakter nevét viseli, aki a holland kávéültetvényeken dolgozó munkások kihasználása ellen lépett fel. 
Ausztriában, Luxemburgban és Olaszországban terjedt el, a Fairtrade Mark Angliában és Írországban volt jellemző, a Rättvisemärkt Svédországban, míg a Reilu Kauppa Finnországban jelölte a méltányos termékeket. Idővel több piaci szereplő is próbálkozott profitgenerálás céljából megalkotni saját márkáját, elveit és feltételrendszerét, mindez azonban a fair trade-del szemben támasztott elvárások elaprózódásához vezetett és magában foglalta a hitelességvesztés rizikóját is. Így egy idő után szükségessé vált, hogy a mögöttes normarendszert szigorúan definiálják és egy intézményesített rendszerbe illesszék. 1997-ben a párhuzamosan múködő címkék összehangolása és az azonos elvárás-rendszer kialakítása céljából létrehozták a Fairtrade Labelling International Organization-t, a fair trade nemzetközi címkéző szervezetét. A bonn-i központú szervezet feladata a nemzetközi márkázási folyamatok harmonizálása, a globális standardok felállítása és a termékek címkézése volt. Az FLO 2002-ben bevezette a nemzetközi FAIRTRADE Certification Mark-ot, amelynek célja a korábbi szétaprózódott területi márkák használatának helyettesítése és a védjegy láthatóságának javítása volt (1. kép). A címkézés egyszerre tanúsította, hogy a termék megfelel bizonyos minőségi és szociális feltételeknek, másrészt az áru azonosítását is segítette. 2004-ben a fenti termékvédjegy mellé egy újabb kategóriát vezettek be, a Fair Trade Organization Mark-ot, amelyet a méltányos kereskedelem elveinek megfelelő szervezetek kaphatnak meg (2. kép).



\section{FAIRTRADE INTERNATIONAL}

1. KÉP

Forrás (Source): [23]

A méltányos kereskedelem termékvédjegye (The FAIRTRADE mark)

A címkék használatának leszabályozásával megteremtődött a méltányos kereskedelem termékeinek szélesebb körben való értékesítésének lehetősége. Ez mérföldkő volt a mozgalom történetében, oly annyira, hogy ma már az értékesített fair trade termékek kétharmada a nagy kiskereskedelmi élelmiszerláncokon keresztül talál gazdát. A nagy disztribúciós csatornákkal való együttmü- ködéssel párhuzamosan megváltozott a kommunikált információ jellege és hangneme is. A nemzetközi szervezetek fejlesztéspolitikáit kritizáló korai szlogeneket felváltották a humánusabb, a hátrányos helyzetű termelők megsegítését középpontba állító és a fogyasztók meggyőzésére koncentráló üzenetek. A FAIRTRADE Mark 2002-es bevezetése óta a világ legszélesebb körben felismert etikai védjegyévé nőtte ki magát [24].

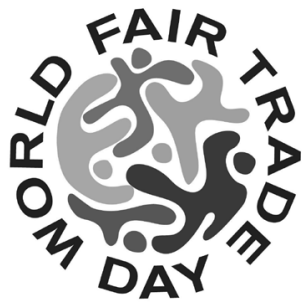

2. KÉP PIC. 2

A méltányos kereskedelem elveinek megfelelő szervezeteket minősítő védjegy (The Fair Trade Organization Mark) Forrás (Source): [25]

A mozgalom a 90-es években elindult a hálózatosodás útján: a szakosodott boltok 1984-ben megszervezték az első Európai Világ Boltok konferenciáját, majd 1994-ben életre hívták a NEWS!-t, az Európai Világ Boltok Hálózatát, a tagok közötti rendszeres információcsere és figyelemformáló kampányok szervezése céljából. A fair trade szimpatizánsai 2002-től nemzetközi világnap keretében ünneplik a méltányos kereskedelmet május második szombatján, 2004-től pedig brüsszeli központtal múködik a FINE Tanácsadó Iroda, amelynek eltökélt célja az európai uniós döntéshozók tájékoztatása és hatékony lobbyerő kifejtése szervezett fellépések, promóciós anyagok, tanulmányok és nyilvános események szervezése által.

\section{A MÉLTÁNYOS KERESKEDELEM HÁTRÁNYA, DILEMMÁK, KRITIKÁK - DiSADVANTAGES, DilemMAS AND CRITICS OF FAIR TRADE}

A mozgalomnak természetesen vannak kritikusai, sőt ellenzői is, akik a következő bekezdésekben olvasható érvekre támaszkodva megkérdőjelezik a védjegy által érvényre juttatható előnyöket.

Booth [17] szerint a különböző etikus kereskedelmi mozgalmak arra ösztönzik a fejlődő országokat, hogy olyan módon szabályozzák a kereskedelmüket, amelyek megengedhetetlenek a különböző 
nemzetközi szabadkereskedelmi egyezmények keretei között. Ráadásul ezekkel a szabályozásokkal azt erősítik, hogy a fejlődő országokban a gazdasági erőforrások a kevésbé hatékony szektorokban rögzüljenek. Az igazságos kereskedelemért küzdő mozgalmak célcsoportja sokszor a legrosszabb kormányzással rendelkező országok köre. Mivel ezek az országok a legszegényebbek közé tartoznak a földön, így náluk a kereskedelmi szabályozás csak növeli a politika befolyását a gazdaságra, azaz magas korrupcióval szembesülnek. Így azonban megkérdőjeleződik a mozgalom helyi múködésének, a prémium közösségi felhasználásának hatásossága és hatékonysága is.

Közgazdászok egy csoportja azzal érvel, hogy nem a szabályozásra kellene nagyobb hangsúlyt fektetni, hanem e helyett a szabadkereskedelem ösztönzésére, hiszen az ebből származó hasznok többszörösen felülmúlhatják a méltányos kereskedelemből realizált előnyöket. Vagyis még mindig inkább a szabadkereskedelem hiánya okozza a kihívást és nem az (elégtelen) jelenléte [17]. Mohan [26] szerint disszonáns, hogy a fair trade hívők egyszerre elégedetlenek a szabadkereskedelemmel szemben és szeretnének minél teljesebb körü szabályozást, másrészt azonban ragaszkodnak a rájuk vonatkozó kereskedelemi előírásokhoz, kedvezményekhez.

A méltányos kereskedelem által garantált fix árral szemben is probléma merül fel. Míg a rendszer a termelői szervezetekbe tömörülő gazdálkodók részére garantál egy fix árat, időközben hátrányosan érinti a nagyobb gazdálkodókat. A rögzített árak mellett a piaci finomhangolások nem tudnak érvényre jutni, így a piac más területein a termelők nagyobbat buknak, mint rögzített feltételek nélkül. A nagy munkaadóknál lecsapódó negatív piaci hatások következtében azok alkalmazottakat bocsáthatnak el, pedig a méretgazdaságosságuk miatt ők azok, akik jobb munka- és szociális körülményeket tudnak biztosítani alkalmazottaiknak, mint a fair trade keretek között múködő kis szervezetek.

A magasabb árak mindeközben túlkínálatot okoznak a piacon, amely viszont az árak rugalmatlansága miatt nehézkesen mozog, így tovább torzítja a piaci folyamatokat, és ez végső soron minden piaci szereplőre kedvezőtlen hatást gyakorol [17].

Griffiths [27] tanulmánya szerint a méltányos kereskedelmi szervezetek nem közölnek egyértelmü adatsorokat arról, hogy valójában milyen öszszeg jut el ténylegesen a termelőhöz, mennyi kerül konkrétan az ő zsebeikbe. Ehelyett a fair trade intézményrendszere különböző anekdotákkal szolgál ahhoz, hogy a mozgalmat és létjogosultságát alátámasszák. Cramer et al. [28] a méltányos kereske- delem hatásvizsgálatának módszertanában látja a problémát, azaz, hogy nagyon is „törékennyé válhat a kutatás alapja” a rosszul megválasztott eszközök és logika miatt.

Renard [20] kiemeli, hogy ahogy a mozgalom egyre népszerúbb lett, úgy jelentek meg egyre többen azok a nagy kiskereskedelmi szereplők, akik a maguk hasznára akarták fordítani az etikus vásárlással kapcsolatosan tapasztalható növekvő érdeklődést. Ezek a világméretű élelmiszeripari vállalatok gyakran saját márkás termékskálát dobnak a piacra és különböző promóciós kampányokba kezdenek, melyek célja a fogyasztó megtévesztése. A saját vállalatukon belül - tehát nem rendelkezve a hivatalos minősítéssel - kialakított „tanúsítványok" az esetek többségében alacsonyabb elvárásokat támasztanak a termelő, a termék és a disztribúció felé, mint a fair trade védjegy. A saját márkás termékek elszaporodása, a védjegyek és márkák túlburjánzása azonban megzavarhatja a fogyasztókat, ami hosszú távon a bizalom és a támogatás elmaradását eredményezheti.

Aggályok merülnek fel az előfinanszírozással kapcsolatban is. Mivel a pénzügyi teljesítés egy része megelőzi a termékek fizikai átadását, így a termelők valójában egy hitelt kapnak kereskedőiktől. Erre azért is van nagy szükség, mert azokban az országokban, ahol a méltányos termékeket előállítják, sokszor még az alapvető emberi és tulajdonjogok betartása is kétséges, így a biztonságos kölcsönök kihelyezésének (és felvételének) a lehetősége nagyon ritka. Bár a hitel használatának bevezetése a piaci folyamatok fejlődéséhez elengedhetetlen, az alapvető cél mégis az intézmények, tulajdonjogok és a jogrend megerősítése lenne a térségben [29].

Sokan kritizálják azt, hogy a méltányos kereskedelem intézményrendszere túlságosan drágán tartja fenn magát. A védjegy használatáért a termelőknek licenszdíjat kell fizetniük, az FLO bevételének csaknem 90\%-a ebből a forrásból származik. Ennek a felét kampányokra, tudatformálásra, tájékoztatásra költik iskolai akciók, reklámok, stb. formájában - tehát gyakorlatilag a saját ismertségüknek növelésére -, ami megkérdőjelezhető egy olyan szervezet esetében, amelynek célja a fejletlen déli országok termelőinek a szegénységi csapdából való kimenekítése.

Probléma lehet, hogy a fair trade a termelői szervezeteket preferálja, melyek gazdaságilag előnytelen konstrukciónak számítanak, főleg, ha kistermelőket tömörít. Ennek oka, hogy elnyomja az ösztönzőket és a technológiai fejlődést meglehetősen megdrágítja. A szövetkezeti forma azzal a negatív hatással is bír, hogy kiöli a tagokból az egyéni motivációt a minőség növelésére, hiszen azt 
úgy is csak szervezeti szinten vizsgálják. Jóllehet a különleges, egyedi kávék nagy piaci potenciált rejtenek magukban, az erre való átállás gyakorlatilag kizárt a szervezeti munkavégzés keretei között [29].

Több tanulmány által alátámasztott a kritika, miszerint amíg a termelő szervezetek gazdálkodói számára valóban észrevehető előnyökkel jár(hat) a védjegy használata, addig a másik, a bérmunkásokat foglalkoztató szervezet alkalmazottjai számára gyakorlatilag nem releváns a fair trade minősítés. Hiába a szervezetük által realizált magasabb ár és hosszabb távú szerződés, a megtapasztalt előnyök nem „gyürüznek” elég messze, és nem érik el a bérmunkásokat [30].

A mozgalom által hirdetett átláthatóság és a fogyasztók minél magasabb szintű tájékoztatásának ígérete is több sebből vérzik: a termelő szervezet megteheti, hogy a világpiacon vásárol például „kommersz” kávét, amelyet aztán saját fair trade termékként, azt megillető méltányos árért értékesít a kereskedőknek. Gyakorlatilag ezt senki sem ellenőrzi.

\section{4. ÖSSZEFOGLALÁs - SUMMARY}

A méltányos kereskedelem áttekintő ismertetése után belátható, hogy a tudatos fogyasztónak egyre több eszköz áll rendelkezésére, ahhoz, hogy érvényre juttassa etikai meggyőződését. A kritikus hangok ellenére a fair trade termékek növekvő népszerüségnek örvendenek, ami tükrözi a 21. századi vásárlók felelősségvállalási hajlandóságát.

A jövőben érdekes kutatási téma lehet a méltányos kereskedelem magyarországi trendjeinek vizsgálata, összehasonlítva a nemzetközi és Európán belüli tendenciákkal, különös tekintettel a fogyasztói szokásokra.

\section{IRODALOMJEGYZÉK - REFERENCES}

[1] Boda Zs.: A méltányos kereskedelem elvei. In: Esély. 2001. (4) URL: http://www.esely. org/kiadvanyok/2001_4/BODA.pdf (Letöltés dátuma: 2013. március 10.)

[2] Gáll V. - Újszászi Gy. (szerk): Útmutató a felelős fogyasztáshoz. In: Védegylet Egyesület. G-Print nyomda, Budapest, 2010.

[3] www.european-fair-trade-association. org: Joining Fair Trade Forces. 2006. február. URL: http://www.european-fairtrade-association.org/efta/Doc/25-anniv.pdf (Letöltés dátuma: 2012. december 30.)
[4] www.fairtrade.net: Common Principles. URL: http://www.fairtrade.net/aims-offairtrade-standards.html\#c3784 (Letöltés dátuma: 2015. január 8.)

[5] Moore, G.: The Fair Trade Movement: Parameters, Issues and Future Research. In: Journal of Business Ethics. 2004. 53 73-86.

[6] www.wfto.com: World Fair Trade Organisation. URL: http://www.wfto.com/ (Letöltés: 2013. november 20.)

[7] www.wfto.com: 10 PRINCIPLES OF FAIR TRADE. URL: http://www.wfto.com/fairtrade/10-principles-fair-trade (Letöltés: 2013. november 20.)

[8] www.fairtrade.net: Fairtrade International. (Letöltés: 2013. november 20.)

[9] www.fairtrade.net: Monitoring the Scope and Benefits of Fairtrade. URL: http:// www.fairtrade.net/fileadmin/user_upload/ content/2009/resources/2014-FairtradeMonitoring-Scope-Benefits-final-web.pdf (Letöltés: 2015. március 8.)

[10]www.fairtrade.net: Fairtrade Product Classification: URL: http://www.fairtrade. net/fileadmin/user_upload/content/2009/ standards/documents/2013-12-10_Product_ Classification_.pdf (Letöltés: 2015. március 10.)

[11] www.fairtrade.travel: Fair Trade Tourism. URL: http://www.fairtrade.travel/ (Letöltés: 2013. november 20.)

[12] Steinrücken, T. -Jaenichen, S.: The Fair Trade Idea: Towards an Economics of Social Labels. In: Journal of Consumer Policy. 2007. 30 201-217.

[13] Töröcsik M.: A tudatos fogyasztást és az egészséget preferáló új fogyasztói trendcsoport, a LOHAS csoport megjelenése Magyarországon. In: Élelmiszer, tápálkozás és marketing. 2007. 4 (1) 41-45.

[14] Antle, J. M.: The New Economics for Agriculture. In: American Journal of Agricultural Economics. 1999. 81 993-1010.

[15] De Pelsmacker, P. - Driesen, L. - Rayp, G.: Are Fair TradeLabels Good Business? Ethics and Coffee Buying Intentions. In: Working Paper. 2003. January. URL: http://www. researchgate.net/publication/24125671_Are_ fair_trade_labels_good_business_Ethics and_coffee_buying_intentions, (Letöltés: 2013. január 03.) 
[16] Bird, K. - Hughes, D.: Ethical Consumerism: The Case of "Fairly-Traded" Coffee. In: Business Ethics: A European Review. 1997. 6 (3) 159-167. URL: http:// onlinelibrary.wiley.com/doi/10.1111/14678608.00063/epdf, (Letöltés: 2015. március 10.)

[17] Booth, P.: Is Trade Justice Just? Is Fair Trade Fair? In: Institute of Economic Affairs Web Publication. 2004. URL: http://www.iea.org. $\mathrm{uk} /$ publications/research/is-trade-justiceis-fair-trade-fair-web-publication (Letöltés: 2013. január 10.)

[18] www.fairtrade.net: Minimum Price and Premium Information. URL: http://www. fairtrade.net/price-and-premium-info.html (Letöltés: 2015. január 4.)

[19] Bowes, J. (szerk.): The Fair Trade Revolutio. Pluto Press, London, 2011.

[20]Renard, M.-C.: Fair Trade: Quality, Market and Conventions. In: Journal of Rural Studies. 2003. 19 87-96.

[21] Ransom, D.: Útmutató a méltányos kereskedelemhez. Védegylet Egyesület, G-print Bt. 2007.

[22]www.en.wikipedia.org: Max Havelaar. URL: http://en.wikipedia.org/wiki/Max_ Havelaar (Letöltés: 2015. február 3.)

[23]http://www.fairtrade.net (Letöltés: 2015. február 3.)

[24]www.fairtrade.com.au: https://fairtrade. com.au/business/fairtrade-your-business (Letöltés: 2015. február 3.) [25]www.peopletree.co.uk: http://www. peopletree.co.uk/about-us/fair-tradefashion/wfto (Letöltés: 2015. február 3.)

[26]Mohan, S.: Fair Trade Without the Froth A Dispassionate Economic Analysis of 'Fair Trade. In: The Institute of Economic Affairs. London, 2010.

[27]Griffith, P.: Lack of Rigour in Defending Fairtrade. In: Economic Affairs. 2010. 30 (2), 45-49. URL: http://www.griffithsspeaker. com/Fairtrade/Lack\%20of\%2origour\%20 in\%2odefending\%2ofairtrade.pdf (Letöltés: 2013. február 10.)

[28] Cramer, C. - Johnston, D. - Mueller, B. - Oya, C. - Sender, J.: How to Do (and How not to Do) Fieldwork on Fair Trade and Rural Poverty. In: Canadian Journal of Development Studies. 01 Apr 2014.

[29]Booth, P. - Whetstone, L.: Half a Cheer for Fair Trade. In: Institute of Economic Affairs web publication. 2007. április 03. URL: http:// www.iea.org.uk/publications/research/halfa-cheer-for-fair-trade-web-publication2007 (Letöltés: 2013. január 10.)

[30]Dragusanu, R. - Giovannucci, D. Nunn, N.: The Economics of Fair Trade. In: NBER Working Paper Series. Working Paper 20357, 2014. július, http://www.nber.org/ papers/w20357 (Letöltés: 2015. május 15.)

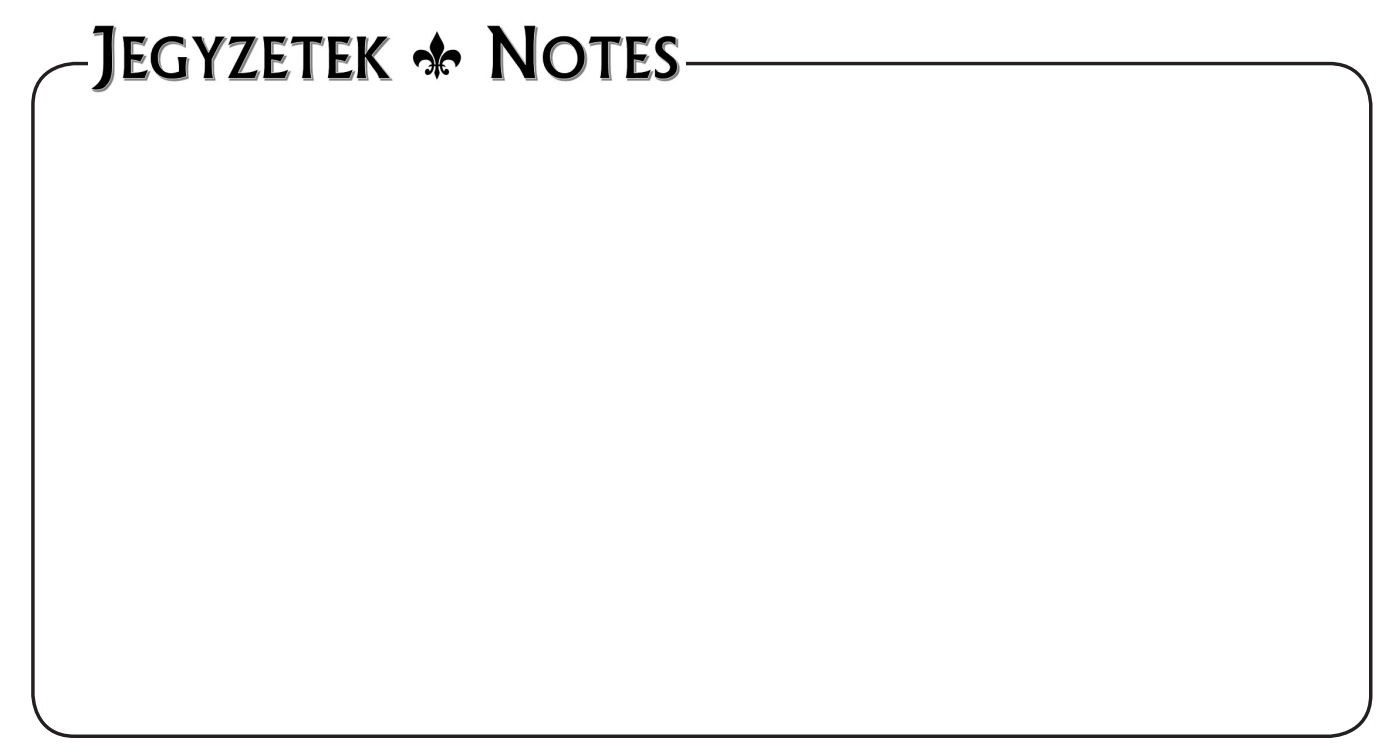




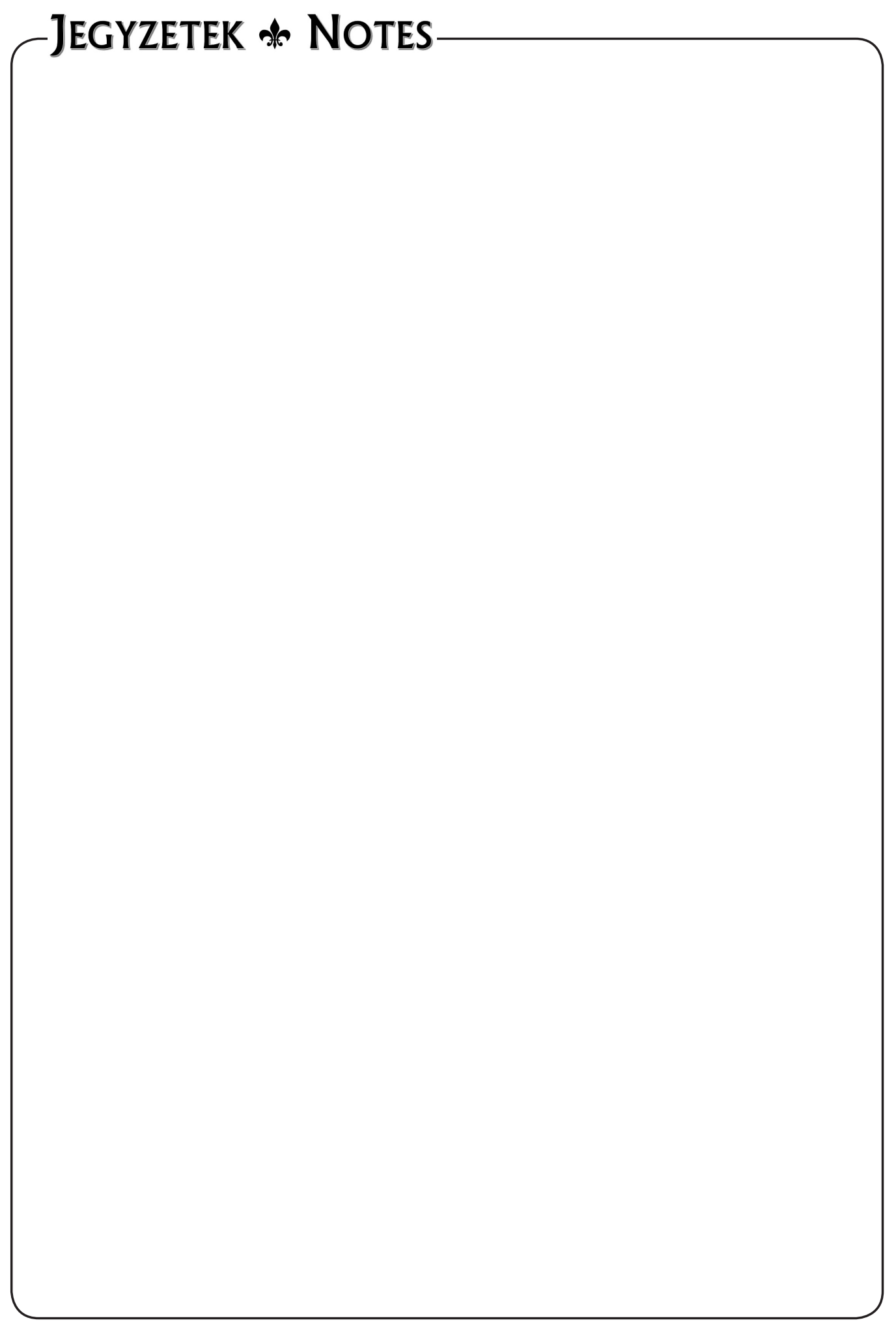

